\title{
ЛЕКСЕМА ЗЕМЉА КАО ОДРАЗ ЈЕЗИЧКЕ СЛИКЕ ПРИРОДЕ
}

У раду који следи испитује се концептуализација земље као компоненте човековог природног окружења с циљем да се резултати анализе укључе у шире истраживање које је усмерено на опис слике природе у српском језику. Полазећи од идеје да су лексичка средства најпоузданији показатељи слике света, у раду је анализирана семантичка структура лексеме земља и семантика фразеологизама у чијем се саставу она налази (нпр. разликовати се као небо и земља, пијан као мајка земља, пупак земље итд.). Резултати анализе показују доминацију домена просторности у свести говорника, али и елементе религијског мишљења, који су нарочито уткани у семантику фразеологизама.

Кључне речи: језичка слика света, лексема земља, лексикографско значење, психолингвистичко значење, фразеологизам.

\section{1. УВОД: ПРЕДМЕТ, ЗАДАЦИ И ТЕОРИЈСКО-МЕТОДОЛОШКИ ОКВИР ИСТРАЖИВАњА}

Лингвокултуролошки опис лексеме земља, предочен у овом раду, комплементаран је лингвокултуролошким обрадама лексема камен и вода (Штрбац, 2019: 285-300; Штасни, 2019: 269-284) и заједно с њима чини део ширег истраживања у којем се на репрезентативном корпусу номинационих јединица настоји описати слика природе у српском језику. У овако усмереном истраживању циљ је представити основне одлике концептуализације природе у српској језичкој заједници које се манифестују у првом реду у његовом лексичком систему. За ову прилику одабран је само један природни елеменат - земља, чије се поимање покушава сагледати на ограниченом корпусу језичких јединица тако да је добијена слика фрагментарна.

Да би се дошло да сазнања о начину на који говорни представник српске језичке заједнице види земљу, као један од најважнијих сегмената

\footnotetext{
*gordana.strbac@ff.uns.ac.rs
} 
природног света који га окружује, као главни предмет истраживања поставља се одређена група лексичких јединица: лексема земља, којом се посматрани елеменат именује, те фразеолошки спојеви у чији састав она улази. ${ }^{1}$ Полази се, наиме, од идеје да језик, тачније његов семантички простор може бити схваћен као главни показатељ механизама људског мишљења, у првом реду сазнајних и спознајних способности. Претпоставља се да су извесни елементи мишљења, али и културе једне заједнице уграђени у семантику јединица језика који се у њој говори. Стога се у истраживању као најважнији методолошки поступак примењује семантичка анализа одабраних лексичких средстава. Она је спроведена на основу њиховог значења, формулисаног у одговарајућим лексикографским приручницима, с циљем да се издвоје они сегменти из којих се могу ишчитати релевантни културолошки подаци.

Под сликом света у овом раду подразумева се уређени скуп знања о стварности који се формира у колективној свести; укључује појмовно знање, али и стереотипе који одређују схватање и интерпретацију одређених појава стварности (Попова, Стерњин, 2007: 51-52). Ова знања уграђена у језик чине језичку слику света, која се може реконструисати, између осталог, на основу његовог лексичког богатства. ${ }^{2}$ У језику су, наиме, садржане оне компоненте које одражавају комуникативно релевантне делове концепта, који улазе у састав слике света. Тако се њиховом анализом заправо откривају елементи концепта који су ушли у семантички простор језика. При томе, треба имати у виду две врсте значења: оно које је представљено у речницима (лексикографско) и оно које се налази у свести носилаца језика (психолингвистичко) (Попова, Стерњин, 2007: 94-104). У овом истраживању у обзир ће бити узета оба типа.

\section{2. СЕМАНТИЧКА СТРУКТУРА ЛЕКСЕМЕ ЗЕМЉА}

2.1. П. Скок (1973: 649-650) издваја два значења лексеме земља, која је свесловенског и прасловенског порекла: прво је синонимно с речју хумус, а друго одговара латинском regio, што наговештава основно рачвање полисемантичке структуре посматране лексеме и у савременом језику.

\footnotetext{
${ }^{1}$ Грађа је ексцерпирана из фразеолошких и дескриптивних речника српског језика; в. списак литературе на крају рада.

2 Детаљније о средствима помоћу којих се може проникнути у језичку слику света в. у: Бартмињски 2011.
} 
Лексикографска обрада лексеме земља у РСАНУ подржава семантички критериј у одређивању примарног значења, а занемарује етимолошки, мада овако представљена полисемантичка структура посматране лексеме указује и на научно, енциклопедијско, и на наивно виђење овог појма у српској говорној заједници. Дакле, у РСАНУ је као примарно издвојено значење према којем дата лексема обележава небеско тело, тј. трећу унутрашњу планету Сунчевог система, као место на којем живимо. Даље се по механизму синегдохе, и то по моделу ЦЕЛИНА ЗА ДЕО, развија семантички садржај под 1.б. 'наша планета односно њена површина као место, простор живота и људске делатности, свет; по религиозном схватању: овај свет, место где проводимо живот од рођења до смрти'. Ово значење ће по истом принципу мотивисати нове садржаје:

2.а. 'водом непокривени део Земљине површине, копно, сухо';

2.б. 'површина Земље, граница Земљине коре и ваздуха; Земљина површина и слојеви, материја испод ње као подлога на којој живимо, тло’;

2.в. 'површина, простор за обраду, искоришћавање, поседање, земљиште'.

Побројане семантичке реализације имају просторну димензију, тј. упућују на већи или мањи простор у којем се одвија живот. Међутим, истом лексемом обележава се и материја различитог порекла која улази у састав тог простора. Метонимијским путем добијени су садржаји:

3.а. 'мека, трошна, растресита материја по Земљиној кори (минералног или органског порекла)';

3.б. 'трошни оксиди неких метала (алуминијума, берилијума и др.)'.

Из значења под тачком 3.а. по метонимијском обрасцу РАСТРЕСИТА МАТЕРИЈА $\rightarrow$ ОНО ШТО СЕ ПРЕТВАРА У РАСТРЕСИТУ МАТЕРИЈУ развИја се садржај 'земаљско, смртно створење, биће које ће се и само претворити у земљу', оквалификован као народни и фигуративан у речнику (нпр. Сељаци ... веле, земља тугује за земљом [покојником, који је земља чим умре] [Мил. М. Ђ. 34, 340, РСАНУ]). У вези је с обичајем сахрањивања покојника јер се по традиционалном уверењу у земљи живот рађа, али и завршава. Људи се на крају свог животног пута враћају под њено окриље тако да она постаје њихово посмртно боравиште (Бандић, 2004: 74). Значење под 3.б. припада специјалном фонду и носи квалификаторе мин. и хем.

Може се рећи да просторном домену припада и семантички садржај у речнику распоређен под тачком 4.а, добијен деловањем синегдохе - 'држава, национална територија, уопште већа територијална јединица'. Иако се 
спацијална компонента подразумева, у њему веома важно место заузимају они елементи који указују на то да се ради о простору који насељава уређена заједница људи, обједињена не само територијално, него и политички, често верски и језички. Мада ове компоненте нису експлициране у лексикографској дефиницији, оне ће мотивисати значење уведено под тачком 4.б, развијено деловањем метонимије - 'становништво одређене државе, веће географске области, народ’.

Под тачком 5 наведена је лексикографска дефиниција 'назив слова 3 у црквенословенској азбуци’. И у овом случају делује метонимијски механизам будући да се цела лексема узима као назив слова којим започиње. Међутим, иако то није експлицитно назначено у речнику, ово значење се може сматрати застарелим.

2.2. Пошто лексема земља није искоришћена као стимулус у АРСЈ, подаци о асоцијативним везама појма именованог њоме с другим појмовима преузети су из ОАРСЈ, у којем је посматрана лексема 910 пута забележена као асоцијација на 113 различитих врста стимулуса. Овом, основном корпусу прикључени су и случајеви у којима се као асоцијати јављају следеће јединице: земље, земљи, землу, земљом, земља била, земьа велика, земьа далека, земьа из сна, земља из снова, земьа мала, земьа мрака, земља најмилија, земља народа, земља наша планета, земља незнаних јунака, земља прошлости, земља рада, земља сељака, земља снова, земља у транзицији, земља чуда. Праћење везе између стимулуса и реакције омогућиће сагледавање мреже појмовних односа формиране у нашој свести око појма земља. ${ }^{3}$

Подаци из речника показују да је у свести говорника српског језика, када се лексема земља јави као реакција, најчешћа представа о држави као уређеној заједници људи. Лексема земља јавила се чак 55 пута као асоцијација на стимулус држава. У овом поимању земља је у 577 случајева забележена као реакција на различите врсте стимулуса. Најчешће, 255 пута, асоцијација је на називе држава, градова, континената, покрајина, народа и сл.: Југославија/југословенски (60+3), Србија/Срби/српски (59+1+1), Канада (42), Немачка/немачка (1+18), Црна Гора (9), америчка (1), Европа (5), Балкан (40), Косово (2), Равна гора (4), Вашингтон (3), Подгориија (2), Москва (1), Хаг (1), Роми (1), руски (1). Земља је 193 пута реакција на

\footnotetext{
${ }^{3}$ Из анализе су искључени стимулуси: крв, огранак, пиће, пре, споредно, за које је врло тешко објаснити везу с асоцијатом земља.
} 
лексеме којима се исказује специфичан однос становника према држави или њихов субјективан утисак као члана дате заједнице: отацбина (54), родољуб (35), ослободити/ослободити се/слобода (14+19+1) патриотизам (26), порекло (11), националиста (7), вољена (7), част (3), јединство/уједињени (4+1), будућност (2), бунт (2), катарза (2), неиздржльв (1), подрика (1), присила (1), терор (1), заједно (1). Лексеме којима се именују државни симболи, затим различити облици државног и друштвеног уређења, различити политички системи, као и читав низ појмова у вези с државном организацијом и животом дате заједнице подстичу асоцијацију земља (103): грб (20), застава (17), моћна (11), федерација (9), глобализам (7), наџија (4), унија (6), демократија (3), култура (3), војник/војници (4), богат/богатство (2+1), порез (2), санкције (2), јак/јача (1+1), режим (1), језик (1), мондијализам (1), политика (1), мудра (1), међународни (1), НАТО (1), прошлост (1), савремен (1), велик (1). И коначно, исту асоцијацију изазивају називи за стране света: јужна/јужни/југ (7+5+1), исток (1), север (1), као и други видови просторне оријентације: далеко (4), овде (2), унутра (2), нигде (1), споља (1), удаљ (1). На основу података из ОАРСЈ могуће је сагледати и извесне стереотипе, мада је на основу фреквенције јављања тешко донети закључак о томе да ли су они својствени целој језичкој заједници, или су то само ставови појединих испитаника. Тако су на стимулус Србија забележене следеће асоцијације: земља велика, земља моја, земља незнаних јунака, земља сељака. Затим, на стимулус Балкан испитаници су дали следеће одговоре: земља из сна / земља из снова, земља у транзицији, земља чуда. Понекад су стереотипи противречни - за једног испитаника Канада је земља мрака, за другог - земља рада, док је за неке земља снова. Свакако да би детаљнија претрага асоцијата на задате стимулусе омогућила прецизнија објашњења.

Земља као материја 164 пута била је одговор на различите врсте стимулуса. Лексеме стимулуси из овог поља углавном именују појмове који се тичу обраде земље и онога што настаје као резултат те обраде: кромпир (48), трактор (40), сељак (19), јагода (4), продајем/продавати (3+2), купус (2), поврће (2), вредност (2), имати (1), мотор (1), остации (2). Знатно је мање оних којима се обележавају физичка својства земље као материје: браон (19), ирн (14), ситни (1). Свега је неколико случајева који потврђују појмовно повезивање земље и смрти, а тичу се обреда сахрањивања посмртних остатака: смрт (3), споменик (1). 
Разноврсне просторне релације такође могу подстаћи асоцијацију земља (85). Углавном се има у виду простор који припада доњем делу вертикалне скале, што доказује представу о земљи као површини по којој се крећемо: доле (24), испод (27), над (15), изнад (4), треснути/треснућу (4+1), метро (3), ногама (3), на (2), низак (2). Иста представом о земљи као површини јавља се на стимулусе: бетон (7), темељ (4), отвореност (2), квадрат (1).

На земљу као планету асоцирали су стимулуси којима се исказује њен облик: округла/округао/круг (81+4+4), око (1) односно који упућују на њен одрживи развој: Ђубре (3), екологија (1).

Земља је асоцирана водом 3 пута, док је асоцијативна веза са стимулусима глуn (1), као (1) највероватније успостављена на основу устаљених израза.

Резултати добијени на основу анализе асоцијативних веза међу лексемама показују доминацију појмовне вредности 'држава'. Међутим, квантитативне податке предочене у њој требало би тумачити с резервом, а више пажње требало би посветити врсти везе успостављене између стимулуса и асоцијата. Наиме, пошто одговори испитаника зависе, пре свега, од природе стимулуса, може се претпоставити да се њихов највећи број односи на земљу као државну заједницу управо због тога што су аутори речника укључили оне стимулусе који су могли изазвати такве реакције, па су појмовне релације Србија-земьа, отаибина-земља, грб-земьа, заставаземља и сл. сасвим очекиване и предвидљиве. Питање је да ли би исти резултати били добијени да је лексема земља искоришћена као стимулус у речнику.

\section{3. ФРАЗЕОЛОГИЗМИ СА САСТАВНИЦОМ ЗЕМљА}

3.1. За потребе анализе прикупљено је педесетак фразеологизама са саставницом земља. Они су семантички шаролики и показују различиту врсту мотивације. На основу њиховог значења и типа мотивисаности може се издвојити неколико фразеолошких скупина.

3.2. Једна група фразеологизама одражава човеково специфично осмишљавање простора, видљивог и невидљивог, у хоризонталном и вертикалном правцу. Његову окосницу чини представа о три космичка 
подручја: небо, земља, подземље. ${ }^{4}$ Две су основне врсте опозитних вертикалних релација успостављене унутар космоса: небо-земља и подземни простор-надземни простор.

3.2.1. Опозиција небо-земља произишла је из симболичке супротности неба као активног и земље као пасивног принципа, тј. мушког и женског аспекта појавног (Gerbran, Ševalije, 2013: 1087), што даље рађа архаичне представе о небу и земљи као брачном пару (СМ, 2001: 198). Ова опозиција у фразеолошком систему српског језика изворни је домен за разноврсне циљне садржаје. Она, на пример, мотивише фразеологизме којима се настоје истаћи непомирљиве разлике међу одређеним појмовима разликовати се као небо и земља, где се компоненте небо и земља разумеју као две опозитне тачке једне скале вредности те се понашају управо као њени еталони. Ипак, у знатној мери ова опозиција подржана је представом о просторној дистанцираности наведених појмова, што потврђују фразеолошке јединице са значењем велике просторне удаљености - далеко као (колико) од неба до земље односно јединице којима се квалификује интензитет и мера у којој се нека активност реализује - од неба до земље 'веома много, веома усрдно (о захваљивању, заклињању и сл.)'. Стереотип о небу и земљи као два одвојена космичка простора, изникао из библијског мита о постанку света, омогућава семантичку интерпретацију дате бинарне опозиције као горе-доле односно далеко-близу (Мршевић Радовић, 2008: 34-39).

У даљим метафоричним транспозицијама просторни домен пресликава се на домен свести те се небо као горња, најудаљенија тачка поистовећује са облицима мишљења који нису засновани на стварности, који припадају свету нереалног и ирационалног. Насупрот небу, земља је простор реалног живота. Ово илуструју примери: бити с главом у облацима, $а$ ногама на земљи 'бити далеко од стварности, живети у илузијама, заносити се', пасти с неба на земљу 'ослободити се илузија, схватити стварност каква јесте', спустити се на земљу 'ослободити се илузија, схватити стварност каква јесте' / сnустити кога на земљу 'ослободити кога илузија, отрезнити кога', стајати (лежати и сл.) на земљи 'бити реалан, стваран'. И само одвајање од земље подразумева одвајање од реалности - ни на небу ни на земљи (бити, налазити се и сл.), лебдети између неба и земље 'бити одвојен од стварности, без ослонца на стварност, без рационалне основе'. У свим

\footnotetext{
${ }^{4}$ М. Елијаде (1999: 44) наводи да је слика три космичке равни врло стара.
} 
овим примерима проналазимо архетипски образац метафоре по којем се просторна близина и чулна доступност доживљавају као могућност спознаје, за разлику од просторне удаљености, која значи одсуство спознаје. У исто време у фразеолошку основу уграђена је народна религиозна представа о небу као оличењу апсолутне духовности, моралне чистоте и сакралности, које се супротставља земаљском свету људи, представљеном као стециште греха и порока. На небу царује вечна радост и лепота, док на земљи људи живе у раду, бригама и страдању (БФСРЯ, 2017: 309).

Небо и земља, као симболи разних врста супротности, актери су и других ситуација које су у основи фразеолошких обрта: саставило се небо и земља 'велики је пљусак, јака је киша', преврнути (покренути) и небо и земљу 'предузети све могуће', свлачити небо и земљу 'заклињати се тешким клетвама, клети се свим и свачим', клети се небом и земљом 'заклињати се свим на свету'. У овим примерима небо и земља не означавају оделите космичке просторе, већ именују комплементарне појмове, делове једне целине за коју у библијској терминологији не постоји хипероним, нпр. свемир, већ се у његовом недостатку користи синтагма небо и земља (Мршевић Радовић 2008: 39).

3.2.2. Земља је граница између људског и хтоничног света, те се у том смислу супротстављају две врсте простора: онај на земљи, намењен живима (свој), и онај испод ње, који је боравиште мртвих (mуђи). Наведена опозиција мотивише настанак два низа фразеологизама супротстављене семантике, која се развија метонимијом. Први низ обухвата примере с општим значењем 'бити жив, живети', у чијој је нефразеолошкој основи садржана слика о боравку човека на површини земље: газити земљу, земља га (је итд.) још држи. Други низ укључује знатно већи број примера којима се именује концепт умирања односно нестајања. Просторна близина земљи значи смрт која ће наступити у временски блиском периоду: вуче кога земља, земља га (је итд.) привлачи. Престанак живота, на другој страни, подразумева смештање у простор испод земље односно у њено окриље или уклањање с њене површине. Простор испод земље је туђ и самим тим

\footnotetext{
5 Људске особине, понашање, положај и човекова егзистенција уопште непосредно су повезани с боравком на земљи. Непожељне људске особине отежавају човеков опстанак на њој - бити (постати) земљи тежак 'бити (постати) веома опасан, омрзнут; постати кобан'.
} 


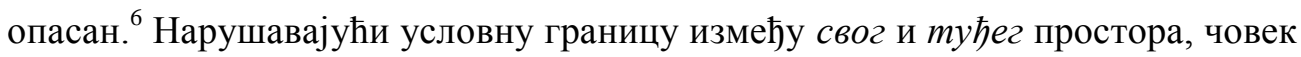
себе доводи у искушење (БФСРЯ, 2017: 639). Ови примери могу имати медијалну и каузативну семантику: бити под (црном) земљом, отићи под (црну) земљу, покрила кога (црна) земља, примила кога земља, загрлила (пољубила) га (их и сл.) је (црна) земља, земља (црна земљь) га крије, отерати (послати) кога у (под) (црну) земљу, збрисати с лица земље (земљи с лица), саставити (сложити, сравнити) кога са (црном) земљом, помирити кога са земљом. Свесно уклањање, нестајање осликава се по истом обрасцу: као да га (их итд.) је земља прогутала (прождрла), као да је (су итд.) у земљу пропао (пропали итд.), побећи у прхлу земљу, нестати (ишчезнути са лица землье). ${ }^{7}$

Непријатност која наступа услед осећања стида или страха поима се на сличан начин као и умирање - пропадањем у земљу, што потврђује пример пропасти (пропадати) у земљу (од стида, страха и сл.). У овој просторној метафори жеља за нестанком поистовећује се са спремношћу да се доспе у пакао, где грешника чека казна за учињено. У религиознодуховном коду културе, који се схвата као скуп моралних смерница и представа, поимање сопствених моралних грешака и грешака у понашању те постојање осећаја стида позитивно се оцењује (БФСРЯ, 2017: 640). Тежак, опасан и несигуран положај осликава се губљењем тла под ногама, нпр. гори (нестаје) коме земља под ногама, што настаје на основу уверења да тврдоћа подлоге, постојаност границе (између горњег и доњег света) обезбеђује човекову стабилност на овом свету (БФСРЯ, 2017: 690). У основи је метафорично пресликавање с конкретног, физичког домена на апстрактни.

Даљом метафоричном транспозицијом и генерализацијом из везе ПРОСТОР ПОД ЗЕМљОМ ЈЕ ТУЋ, ОПАСАН, НЕДОКУЧИВ настају примери у којима се подземни свет разуме као нешто негативно уопште. Дакле, предлошки спој испод земље употребљен уз глагол детерминише радњу именовану њиме као тајну и подмуклу, а тиме се у исто време квалификује и сам

\footnotetext{
${ }^{6}$ Израз онај свет у значењу 'свет мртвих' управо одражава двојну поделу простора на свој и туђ.

7 Пригодан израз који се користи приликом опраштања с покојником или када се помене његово име - лака му (црна) земља, нека му је лака (ирна) земља, одражава уверење о постојању могућности да покојник не буде примљен у свет мртвих или да му боравак у том свету буде тежак и непријатан. Д. Мршевић Радовић (2008: 172) сматра да је овај израз управо мотивисан физичким својствима земље, њеном тежином (будући да је на гробљима земљиште обично глиновито) и хладноћом.
} 
носилац активности; глаголско-именички фразеологизам метнути шта $y$ земљу има значење 'поништити, обезвредити шта'.

3.3. С обзиром на хоризонталну распрострањеност, земља служи као мера висине или спровођења одређене активности: нема кога педаљ од земље 'бити малена раста', сравнити шта, кога (сравнати, изравнати) са земљом (с лицем земље и сл.) 'срушити, разорити до темеља, потпуно уништити', срушити шта до земље 'сасвим уништити, упропастити'.

Фразеологизам кад је Бог по земљи ходао у значењу 'врло давно, у старо доба, време' садржана је културна конотација у виду религијских представа о свету. Овим фразеологизмом тренутак далеке прошлости исказан је асоцирањем на догађај карактеристичан за митско време прапочетка и рајског блаженства у којем су човек и бог били сасвим блиски, при чему, према мишљењу В. Чајкановића, овде треба имати у виду нашег старог паганског бога даваоца (Мршевић Радовић, 2008: 71-79).

3.4. Омања фразеолошка скупина показује да је код говорника српског језика изражена свест о земљи као материјалној основи људског опстанка. У полазној структури фразеологизма избијати хлеб из земље знојем (с муком и сл.) са значењем 'с тешком, великом муком зарађивати, издржавати се’ осликана је обрада земље као услов живота, која је у свести говорника повезана с мукотрпним радом. Ова слика своје упориште има у библијском тексту, у Божјим речима намењеним Адаму: „Са знојем лица својега јешћеш хљеб” (Прва књига Мојсијева, гл. 3, 19). Полазна ситуација се уопштава тако да се у процесу фразеологизације добија израз којим се денотира тежак рад уопште. Истом концептуалном пољу, које укључује земљу као основу људске егзистенције, припада и пример гристи земљу 'сиротовати, гладовати'. Представе о плодоносној моћи земље илуструје фразеологизам изникнути (појавити се) као из земље 'ненадно, одједном се појавити'. Фразеолошки садржај 'радити узалудан, мукотрпан, бесмислен посао' подстакнут је сликом обављања бесмислене активности - мести капом землу.

Земљи се, због њене хранитељске улоге, додељује посебно место не само у материјалном већ и у духовном животу човека. Ова улога утицала је на то да се земља почиње посматрати као еталон појединих људских особина и стања: јак као земља 'врло јак, необично снажан', пијан као (мајка) земља 'сасвим пијан, мртав пијан', напити се (опити се) као (мајка) земља 'сасвим се опити, напити се потпуно до пијанства'. Ипак, концептуализацију интелектуалних људских особина помоћу земље - глуn 
као земља 'врло глуп', тешко је објаснити на овај начин с обзиром на негативну конотацију посматраног израза, која је мотивисана истим таквим односом према појму именованом датом лексемом.

У контексту људског опстанка поседовање земљишта такође је било драгоцено. Наиме, у српској традиционалној култури као свето третирано је првенствено земљиште сопственог имања, а његово неоправдано присвајање сматрано је неморалним чином и повредом табуа (Бандић, 2004: 75). Ово веровање уграђено је у процес разумевања непопустљивости и тврдоглаве истрајности - не одступити (уступити) ни педаљ (педља) земље 'нимало не попустити, не одступити'.

Мајчинска функција земље, заснована на симболици рађања и обнове, доприноси у знатној мери њеној персонификацији, што одражава израз пупак земље, којим се квалификује средиште или најважније место нечега. У ову метафоричну слику уграђен је симболизам средишта. Наиме, три космичка подручја (небо, земља и подземље) повезана су у средишту помоћу једне осе. У јеврејском, вавилонском и индоевропском свету то средиште чинио је храм, као зона укрштања вишег (божанског), земаљског и подземног света. Градови, храмови и палате, сматрани средиштем света, само су реплике које понављају исту архаичну слику - космичку планину, дрво света или средишњи стуб који подупире космичке равни. Врх космичке планине је највиша тачка на земљи, али и пупак земље, тачка из које је почело стварање. У једном рабинском тексту стоји да је Бог почео да ствара свет од пупка, као што је то случај са заметком. При томе, стварање човека реплика је космогоније тако да се и оно одиграло у средишту. Рај у којем је створен Адам налази се у средишту космоса и представља пупак земље. Према једном сиријском предању, налазио се на планини која је била виша од свих других. Адам је створен на истом месту где ће касније бити подигнут Исусов крст (Елијаде, 1999: 44-48).

3.5. Семантичка компонента 'држава' садржана је у значењу свега два фразеологизма: земља дембелија 'измишљена земља у којој тече мед и млеко, у којој се не мора ништа радити' и обећана земља 'срећна богата земља или место, рај у идеалном или материјалном смислу; према Библији Палестина'.

Први пример развија своју семантику на основу турцизма дембел (дембелан) у значењу 'лењ човек, ленштина, готован'. Отуда би земља у којој живи дембел била уређена по његовим мерилима: то је земља у којој се добробит стиче без икаквог труда. 
Други пример, који је иначе интернационализам, како показује речничка дефиниција, може имати два значења, при чему су оба део религијског концепта. Она се изводе на основу библијске приче о Мојсију, који је ослободио потлачено јеврејско становништво од египатског ропства и повео га у Ханан, отаџбину праотаца Аврама, Исака и Јакова. У самом називу садржан је податак о природи те земље - 'земља равничарска' или 'земља пурпурне вуне', пошто је била чувена по производњи драгоцене боје. Њу је Херодот назвао Палестина, према речи Пелиштим, библијском имену за Филистејце, који су у тринаестом веку пре наше ере заузимали јужне обале Ханана. Низијски појас Ханана дуж Средоземног мора имао је необично плодно тло, што је било повољно за развој земљорадње и повртарства. О плодности те земље сведочи и египатски достојанственик Синухе, који је био принуђен да напусти Египат и насели се у Ханан. По његовим речима, у тој земљи смокве и грожђе расли су у изобиљу, па је вина било више него воде; дрвеће се савијало до свакаквог воћа; меда и уља увек је било довољно; успевали су јечам и пшеница итд. (Косидовски, 1993: 9395). Стога се у Библији Ханан назива земљом у којој тече мед и млеко: „И рече Господ: добро видјех невољу народа својега у Мисиру, и чух вику његову од зла које му чине настојници, јер познах муку његову. И сиђох да га избавим из руку Мисирских, и да га изведем из оне земље у земљу добру и пространу, у земљу гдје млијеко и мед тече, на мјесто гдје су Хананеји и Хетеји и Амореји и Ферезеји и Јевеји и Јевусеји" (Друга књига Мојсијева, гл. 3, 7-8). Претпостављамо да се спој обећана земља, који је забележен у Посланици апостола Павла Јеврејима („Вјером дође Авраам у земљу обећану...”), примарно односио на Палестину, а да је садржај 'срећна богата земља или место, рај у идеалном или материјалном смислу' настао секундарно, уопштавањем. Земља у коју су Јевреји стигли после дугих година лутања била је предмет ьихове узавреле маште, страсне жеље и тежње, те је у том смислу она идеализована. Тој земљи даље се приписује статус универзалне човекове тежње ка савршеном животу, због чега фразеологизам у целини има улогу еталона, тј. мере онога о чему се машта, чему се тежи (БФСРЯ, 2017: 237-238).

\section{4. ЗАКЉУЧАК}

Лингвокултуролошка обележја лексеме земља разматрана су с циљем да се прикључе ширем истраживању у којем ће бити сагледани облици разумевања и виђења природног света својствени говорницима српског 
језика. Овом приликом узето је у обзир значење посматране лексеме и семантика фразеолошких јединица у чијем се лексичком саставу она налази. Анализом је обухваћено педесетак фразеологизама.

Семантичка структура лексеме земља анализирана је с обзиром на лексикографске дефиниције предочене у одговарајућим речницима и с обзиром на њено психолингвистичко значење, садржано у свести носилаца језика, до којег се долази интерпретацијом података из асоцијативних речника српског језика. Показује се да је у оба случаја доминантна компонента просторности, што потврђује израженост овог когнитивног обележја и у свести говорника, а резултат је човекових перцептивних способности. Наиме, лексемом земља денотирају се различити видови просторности - од парцеле као мање омеђене замљишне целине, преко површинског слоја као подлоге на којој се одвија живот, до планете као небеског тела унутар васионе. Због тога је механизам синегдохе најзаступљенији у развоју полисемије. Елементе религијског виђења стварности налазимо у значењу лексеме земља којим се недвосмислено сугерише представа о постојању овог, видљивог, чулима доступног света и оностраног, невидљивог који се сматра посмртним боравиштем људи.

Елементи културе уткани су у семантику фразеолошких средстава језика као показатељи религијског облика мишљења. Изрази попут разликовати се као небо и земља, далеко као (колико) од неба до земље, бити с главом у облачима, а ногама на земљи и сл. одражавју митско осмишљавање простора по којем се као најочигледнија издваја опозиција небо-земља. Мајчинска функција земље, заснована на симболици рађања, уочљива је у примерима пијан као (мајка) земља, пупак земље итд. Библијским садржајем мотивисан је фразеологизам обећана земља.

Како показује ово ограничено истраживање, лингвокултуролошки приступ у анализи лексичког материјала превазилази границе језика и залази у простор мишљења откривајући најважније карактеристике менталитета једне језичке заједнице. 
Gordana Štrbac

LEXEME EARTH AS REFLECTION OF THE LANGUAGE PICTURE OF THE NATURE

Summary

In this paper the language units were analyzed in order to present a language picture of the nature. The lexeme earth was selected: its polysemantic structure was examined, based on lexicographic and psycholinguistic meaning, and also the phraseology containing this lexeme was also considered (for example, in Serbian, spustiti se na zemlju, ni na nebu ni na zemlji, obećana zemlja).

The analysis shows that the meaning of the examined units contains two types of elements: 1. the semantic features reflecting cognitive characteristics of the concept as a result of human perception; 2. cultural components as an indicator of the religious form of thinking.

Key words: language picture of the world, the lexeme earth, lexicographic meaning, psycholinguistic meaning, phraseologism.

\section{ЛИТЕРАТУРА}

ARSJ - Piper, P., - Dragićević, R. - Stefanović, M. (2005). Asocijativni rečnik srpskoga jezika. Beograd: Beogradska knjiga - Službeni list SCG Filološki fakultet u Beogradu (штампано ћирилицом).

Bandić, D. (2004). Narodna religija Srba u 100 pojmova. Beograd: Nolit (штампано ћирилицом).

Bartminjski, J. (2011). Jezik - Slika - Svet. Beograd: SlovoSlavia (штампано ћирилицом).

BFSR - Bol'šoj frazeologičeskij slovar' russkogo jazyka. Značenie. Upotreblenie. Kul'turologičeskij komentarij (red. V. N. Telija). Moskva: Izdatel'stvo „Slovari XXI veka”, 2017. (штампано ћирилицом).

Elijade, M. (1999). Slike i simboli. Ogledi o magijsko-religijskoj simbolici. Novi Sad - Sremski Karlovci: Izdavačka knjižarnica Zorana Stojanovića (штампано ћирилицом).

Gerbran, A. - Ševalije, Ž. (2013). Rečnik simbola (mitovi, snovi, običaji, postupci, oblici, likovi, boje). Novi Sad: Stylos art - IZ Kiša.

Kosidovski, Z. (1993). Biblijske legende. Beograd: Srpska književna zadruga (штампано ћирилицом).

Matešić, J. (1982). Frazeološki rječnik hrvatskoga ili srpskog jezika. Zagreb: Školska knjiga. 
Mršević Radović D. (2008). Frazeologija i nacionalna kultura. Beograd: Društvo za srpski jezik i književnost Srbije (штампано ћирилицом).

OARSJ - Dragićević, R. - Piper, P. - Stefanović, M. (2011). Obratni asocijativni rečnik srpskoga jezika. Od reakcije ka stimulusu. Beograd: Beogradska knjiga - Službeni glasnik (штампано ћирилицом).

Popova, Z. D. - Sternin, I. A. (2007). Kognitivnaja lingvistika. Moskva: „Vostok Zapad" (штампано ћирилицом).

RMS - Rečnik srpskohrvatskog kknjiževnog jezika, I-VI. Novi Sad: Matica srpska, 1967-1976 (штампано ћирилицом).

RSANU - Rečnik srpskohrvatskog književnog i narodnog jezika, I-. Beograd: SANU - Institut za srpski jezik SANU, 1959-.

Skok, P. (1971-1974). Etimologijski rječnik hrvatskoga ili srpskoga jezika. Zagreb: Jugoslavenska akademija znanosti i umjetnosti.

SM - Slovenska mitologija. Enciklopedijski rečnik (red. S. Tolstoj - Lj. Radenković). Beograd: Zepter book world, 2001. (штампано ћирилицом).

Štasni, G. (2019). Jezička slika vode. Godišnjak Filozofskog fakulteta u Novom Sadu, XLIV/1, 269-284. (штампано ћирилицом).

Štrbac, G. (2019). Lingvokulturološki status lekseme kamen. Godišnjak Filozofskog fakulteta u Novom Sadu, XLIV/1, 285-300. (штампано ћирилицом). 